\title{
BIOLOGY AND FERTILITY LIFE TABLE OF MAHANARVA FIMBRIOLATA (STÅL) (HEMIPTERA: CERCOPIDAE) IN SUGARCANE
}

\author{
José Francisco Garcia1*; Paulo Sérgio Machado Botelho²; José Roberto Postali Parra ${ }^{3}$ \\ ${ }^{1}$ USP/ESALQ - Programa de Pós-graduação em Entomologia Agrícola. \\ ${ }^{2}$ UFSCar/CCA - Depto. de Biotecnologia Vegetal - C.P. 153 - 13600-970 - Araras, SP - Brasil. \\ ${ }^{3}$ USP/ESALQ - Depto. de Entomologia, Fitopatologia e Zoologia Agrícola - C.P. 09 - 13418-900 - Piracicaba, \\ SP - Brasil. \\ *Corresponding author <garciajf@gmail.com>
}

\begin{abstract}
Mahanarva fimbriolata (Stål) (Hemiptera: Cercopidae) is the most important pest of sugarcane harvested without the use of fire to burn leaf trash. Its biology was studied for three generations in order to obtain basic information about its life cycle. A fertility life table was used to evaluate the quality of laboratory-reared insects. Data were obtained at a temperature of $25 \pm 1^{\circ} \mathrm{C}$, RH of $70 \pm 10 \%$, and a 14hour photophase. The incubation period lasted 21 days with a viability of $81 \%$; the nymph stage had a duration of 37 days, with a 94\% viability; the male and female longevities were 18 and 23 days, respectively, with a pre-oviposition period of 5 days and an oviposition period of 16 days, with a fecundity of 342 eggs, with a life-cycle (egg-adult) of 60 days. A net reproductive rate (Ro) of 131 females produced per female per generation was measured, with a finite rate of increase $(\lambda)$ of 1.085 . The fertility life table proved to be adequate to be evaluate the quality of laboratory-reared $M$. fimbriolata populations.
\end{abstract}

Key words: Insecta, sugarcane spittlebug, fecundity

\section{BIOLOGIA E TABELA DE VIDA DE FERTILIDADE DE MAHANARVA FIMBRIOLATA (STÅL) (HEMIPTERA: CERCOPIDAE) EM CANA-DE-AÇÚCAR}

\begin{abstract}
RESUMO: A cigarrinha-das-raízes, Mahanarva fimbriolata (Stål) (Hemiptera: Cercopidae), é considerada a principal praga da cana-de-açúcar colhida sem despalha a fogo no Brasil. Neste trabalho, estudou-se sua biologia por três gerações, visando obter informações básicas sobre seu ciclo de vida. Para avaliar a qualidade dos insetos criados em laboratório utilizou-se a tabela de vida de fertilidade. Os dados foram obtidos sob temperatura de $25 \pm 1^{\circ} \mathrm{C}$, UR de $70 \pm 10 \%$ e fotofase de 14 horas. O período de incubação foi de 21 dias e a viabilidade de $81 \%$; a duração da fase ninfal foi de 37 dias, com viabilidade de $94 \%$; as longevidades de machos e de fêmeas foram de 18 e 23 dias respectivamente, com período de pré-oviposição de 5 dias e oviposição de 16 dias, com fecundidade de 342 ovos, com duração do ciclo de vida (ovo-adulto) de 60 dias. A taxa líquida de reprodução (Ro) foi de 131 fêmeas geradas por fêmea por geração e a taxa finita de aumento $(\lambda)$ de 1,085. A tabela de vida de fertilidade mostrou-se adequada para avaliar a qualidade de populações de $M$. fimbriolata mantidas em criação de laboratório.

Palavras-chave: Insecta, cigarrinha-das-raízes, fecundidade
\end{abstract}

\section{INTRODUCTION}

Spittlebugs belonging to the family Cercopidae constitute important pests on various crops, including sugarcane. Although there have been reports on their presence in several parts of the world, Fewkes (1969) verified that they are common sugarcane pests only in the New World, occurring in North, Central, and South America, and are also present in the islands of Trinidad \& Tobago, Grenada, Jamaica, and Cuba. Guagliumi (1968) reported that the first references on sugarcanedamaging cercopids in Brazil date 1918. Among these, the genus Mahanarva is worth mentioning because of its wide distribution and of the important damage it causes.

Mahanarva fimbriolata (Stål) (Hemiptera: Cercopidae) is the most important pest of sugarcane harvested without the use of fire to burn leaf trash. In spite of the current economic importance of the sugarcane spittlebug, advances in the management of this pest have been limited by the lack of basic information on its biology and behavior, since it has been considered a secondary pest in sugarcane harvested after burning. 
In this study, the developmental time of immature stages and reproductive parameters of $M$. fimbriolata were investigated during three generations, in order to obtain information on the insect's life cycle. A fertility life table was used to evaluate the quality of laboratory-reared insects.

\section{MATERIAL AND METHODS}

The research was carried out in Piracicaba, SP, $\left(22^{\circ} 42^{\prime} \mathrm{S}, 47^{\circ} 37^{\prime} \mathrm{W}\right.$; altitude $\left.546 \mathrm{~m}\right)$ during the period January to October 2002, at a temperature of 25 $\pm 1^{\circ} \mathrm{C}$, relative humidity of $70 \pm 10 \%$ and a 14 -hour photophase. The insects came from a laboratory rearing stock, obtained according to the technique described by Garcia (2002).

The following sugarcane spittlebug life-cycle parameters were estimated for three generations: egg - duration of the embryonic development period and viability; nymph - duration of the nymphal period and viability; adult - pre-oviposition and oviposition period, fecundity, and longevity.

Eggs laid on the third day of oviposition were used to determine the duration of the embryonic period and viability, distributed on Plexiglas ${ }^{\circledR}$ plates (6 $\mathrm{cm}$ diameter $\times 2 \mathrm{~cm}$ height), lined with autoclaved filter paper moistened with distilled water. The number of nymphs hatched per plate was recorded daily. The experimental design was completely randomized, with five replicates, consisting of 100 eggs each.

Sugarcane seedlings were used to evaluate duration and viability of the nymphal period, placed in $500 \mathrm{~mL}$ containers, sealed with a plastic lid containing a vent hole in the middle ( $2 \mathrm{~cm}$ diameter). Ten first instar nymphs were placed in each container; daily evaluations were made, and the number of emerged adults was recorded. A completely randomized experimental design was also adopted, with ten replicates, each consisting of ten $M$. fimbriolata nymphs.

In order to calculate potential lifetime fecundity (number of eggs/female) and age-specific fecun- dity (mean number of eggs/day), an oviposition period elapsed between the first and last observed egg-layings was considered. The numbers of live and dead females were counted for each evaluation. The mean daily longevity values and oviposition period were compared. A completely randomized experimental design was adopted, with 40 replicates, each consisting of a $M$. fimbriolata pair.

The biological data were submitted to analysis of variance and the means were compared by the Tukey test $(P \leq 0.05)$, using the SANEST 2.0 software program. The life table parameters and their corresponding standard errors were estimated by the jackknife technique (Meyer et al., 1986), and the means were compared by unilateral "t" tests, using the LIFETABLE.SAS software program developed by Maia et al. (2000) in the SAS System environment.

\section{RESULTS AND DISCUSSION}

The mean duration of the embryonic development period was 21.0 days, with a viability of $81.0 \%$; these parameters were not different among the three generations (Table 1). Thus, under controlled temperature, relative humidity, and photoperiod conditions, the duration and viability of the egg stage of $M$. fimbriolata presented similar behavior regardless of generation, attesting to the adaptation of the insect to the conditions in which it was maintained. The values obtained did not depart from the mean, which confirms the above statement and attests that, under the conditions in which the insects were maintained, they present uniform development (Table 1). A variation of seven days was observed when the egg-stage duration data are contrasted against the existing literature. Moreira (1925) found a mean period of 15 days; however, since the conditions under which this information was obtained are not mentioned, it is not feasible to establish a comparison with the data here obtained.

The nymph development period also did not show differences among the generations under study;

Table 1 - Mean duration (days) and viability (\%) \pm standard error, and variation interval (in parenthesis) for the egg and nymph stage of the sugarcane spittlebug, Mahanarva fimbriolata, for three consecutive generations. Temperature: $25 \pm 1^{\circ} \mathrm{C}$, RH: $70 \pm 10 \%$, and photophase: 14 hours.

\begin{tabular}{llcccc}
\hline \multirow{2}{*}{ Generation } & \multicolumn{2}{c}{ Duration } & & \multicolumn{2}{c}{ Nymph } \\
\cline { 2 - 3 } \cline { 5 - 6 } & $20.6 \pm 0.40 *(18-24)$ & $80.8 \pm 2.49 *(75-90)$ & & $36.8 \pm 0.58 *(34-43)$ & $88.0 \pm 4.89 *(70-100)$ \\
2 & $21.0 \pm 0.31(19-25)$ & $79.8 \pm 2.95(73-89)$ & & $37.0 \pm 0.31(33-44)$ & $96.0 \pm 2.44(90-100)$ \\
3 & $20.8 \pm 0.20(19-26)$ & $82.4 \pm 5.01(73-100)$ & & $37.4 \pm 0.24(35-43)$ & $98.0 \pm 2.00(90-100)$ \\
\hline Mean & $20.8 \pm 0.30(18-26)$ & $81.0 \pm 3.48(73-100)$ & & $37.1 \pm 0.38(33-44)$ & $94.0 \pm 3.11(70-100)$ \\
\hline
\end{tabular}

*There were no statistical differences between means. 
an average value of 37.1 days was obtained, with $94.0 \%$ viability (Table 1 ).

A comparison between our duration data with those of a close species, $M$. posticata, obtained by Marques (1976) in the laboratory (fluctuating average temperature and relative humidity of $27.4^{\circ} \mathrm{C}$ and $72.6 \%$, respectively), demonstrated a variation of about 11 days (mean of 47.9 days, with a variation interval from 34 to 65 days).

The data obtained in this study demonstrate the importance of a strict control of temperature, relative humidity, photoperiod and quality of the food provided to the insects for similar durations to be obtained at this stage of the insect cycle, for consecutive generations in laboratory, in order to inhibit egg diapause. A lack of control in any of those variables may affect nymph stage duration and viability and compromise the adult stage.

The sex ratio observed was practically the same in the three generations, with a value near 0.50 . There was no difference ( $x^{2}$ test) between the observed and the expected sex ratio, of one male to one female.

The mean female longevity was 22.6 days, while male longevity was 17.6 days; the values for males and females did not differ for the three generations. When the longevity of males and females are compared within generations, it can be seen that there was a difference between sexes, with females living longer than males (Table 2). However, M. fimbriolata survival obeys Weibull's model for both sexes, indicating that the rearing system did not change the physi- ology of the insect, since it was possible to predict this parameter, which facilitates laboratory rearing.

In comparing the longevity results for $M$. fimbriolata and $M$. posticata, it can be observed that Marques (1976) obtained a mean longevity of seven days for males and 21 days for females; no reference was made with regard to the conditions in which those values were obtained.

The mean pre-oviposition period determined for the generations was 5.0 days, without differences between generation means (Table 3).

The oviposition period was 16.1 days on average; no difference between generations was observed for the oviposition period as well (Table 3). A comparison of these results with those obtained by Marques (1976) for M. posticata shows pre-oviposition and oviposition period differences of 3.1 and 6.7 days, respectively.

The mean number of eggs/female in the three generations was 342.1 eggs per female, without differences between generations (Table 3). Marques (1976) observed a mean fecundity of 101.7 eggs/female in $M$. posticata. Although these are distinct species, considerable variation exists in those data, which should be attributed to the fact that they were obtained under different conditions.

The net reproductive rate (Ro), mean interval between generations $(T)$, intrinsic rate of increase $\left(r_{m}\right)$, and finite rate of increase $(\lambda)$ were $131.3 ; 60.2 ; 0.081$; and 1.085, respectively (Table 4). No difference was observed when each parameter was analyzed individually.

Table 2 - Mean longevity (days) \pm standard error, and variation intervals (in parenthesis) of sugarcane spittlebug (Mahanarva fimbriolata) males and females, for three consecutive generations. Temperature: $25 \pm 1^{\circ} \mathrm{C}$, RH: $70 \pm 10 \%$, and photophase: 14 hours.

\begin{tabular}{lll}
\hline Generation & \multicolumn{1}{c}{ Male } & \multicolumn{1}{c}{ Female } \\
\hline 1 & $18.6 \pm 1.49 \mathrm{a}^{*}(6-35)$ & $23.5 \pm 1.89 \mathrm{~b}^{*}(5-40)$ \\
2 & $17.4 \pm 1.43 \mathrm{a}(7-43)$ & $22.5 \pm 2.17 \mathrm{~b}(7-45)$ \\
3 & $16.9 \pm 1.61 \mathrm{a}(6-47)$ & $21.8 \pm 1.73 \mathrm{~b}(7-40)$ \\
\hline Mean & $17.6 \pm 1.51(6-47)$ & $22.6 \pm 1.93(5-45)$ \\
\hline
\end{tabular}

*Means followed by the same letter in the row do not differ statistically among themselves by Tukey test $(P \leq 0.05)$.

Table 3 - Mean pre-oviposition and oviposition period (days) and fecundity \pm standard error and variation intervals (in parenthesis) of sugarcane spittlebug (Mahanarva fimbriolata) females, for three consecutive generations. Temperature: $25 \pm 1^{\circ} \mathrm{C}$, RH: $70 \pm 10 \%$, and photophase: 14 hours.

\begin{tabular}{lccc}
\hline Generation & Pre-oviposition & Oviposition & Fecundity \\
\hline 1 & $4.8 \pm 0.18^{*}(2-7)$ & $18.4 \pm 1.90^{*}(1-36)$ & $379.8 \pm 44.64 *(13-977)$ \\
2 & $5.1 \pm 0.11(3-10)$ & $16.9 \pm 1.83(1-41)$ & $338.3 \pm 51.92(11-1369)$ \\
3 & $5.0 \pm 0.14(4-8)$ & $13.1 \pm 1.54(1-35)$ & $308.1 \pm 38.84(23-1072)$ \\
\hline Mean & $5.0 \pm 0.14(2-10)$ & $16.1 \pm 1.76(1-41)$ & $342.1 \pm 45.13(11-1369)$ \\
\hline
\end{tabular}

*There were no statistical differences between means. 
Table 4 - Estimates of parameters associated with fertility life tables \pm standard error and $p$ values corresponding to $t$ tests, for comparison between treatment pairs, using variances estimated by the jackknife method for sugarcane spittlebug, Mahanarva fimbriolata, for three consecutive generations. Temperature: $25 \pm 1^{\circ} \mathrm{C}, \mathrm{RH}: 70 \pm 10 \%$, and photophase: 14 hours.

\begin{tabular}{lcccc}
\hline \multirow{2}{*}{ Generation } & \multicolumn{3}{c}{ Parameters } \\
\cline { 2 - 5 } & Ro & $\mathrm{T}$ & $\mathrm{r}_{\mathrm{m}}$ & $\lambda$ \\
\hline 1 & $135.0 \pm 15.87 *$ & $60.4 \pm 0.48^{*}$ & $0.081 \pm 0.0016^{*}$ & $1.085 \pm 0.0018^{*}$ \\
2 & $129.6 \pm 19.89$ & $61.0 \pm 0.84$ & $0.080 \pm 0.0019$ & $1.083 \pm 0.0012$ \\
3 & $129.4 \pm 16.31$ & $59.3 \pm 0.97$ & $0.082 \pm 0.0014$ & $1.086 \pm 0.0015$ \\
\hline Mean & $131.3 \pm 17.36$ & $60.2 \pm 0.76$ & $0.081 \pm 0.0016$ & $1.085 \pm 0.0015$ \\
\hline
\end{tabular}

*There were no statistical differences between means.

The data obtained for net reproductive rate (Ro) indicate that, at each generation, the $M$. fimbriolata females had the same capacity to increase their population and that, on average, this increase was $8.5 \%$, as attested by the finite rate of increase (l). In this case also, the generations were not different among themselves.

The parameters evaluated by the fertility life table demonstrate that the biological behavior of the pest was similar in the observed generations.

Since there was no difference between the values of the respective parameters, it can be stated that the technique developed to rear M. fimbriolata on sugarcane plants allows the insect to be maintained with quality and uninterruptedly for consecutive generations in the laboratory; such fact does not occur in nature, since $M$. fimbriolata interrupts its cycle in the cooler and drier months of the year for the conditions of the State of São Paulo (El-Kadi, 1977 and Mendes et al., 1977).

Thus, since the similarity of the data obtained for the three generations constitute a reliable support to admit that the technique developed to rear $M$. fimbriolata preserves the traits of the species, it can be used to obtain insects in the laboratory comparable to those grown in nature, regardless of season of the year, to be used in studies that require these insects.

There was no biological $M$. fimbriolata alteration along generations and fertility life tables can be used to control the quality of sugarcane spittlebug populations in the laboratory.

\section{ACKNOWLEDGEMENTS}

To CAPES, for the research scholarship granted to the first author. To FAPESP, for financial support, project no. 99/08585-9. To CTC, Piracicaba/ $\mathrm{SP}$, for supplying sugarcane seedlings.

\section{REFERENCES}

EL-KADI, M.K. Novas perspectivas no controle de cigarrinhas. In: CONGRESSO BRASILEIRO DE ENTOMOLOGIA, 4., Goiânia, 1977. Resumos. Goiânia: SEB, 1977. p.58-67.

FEWKES, D.W. The biology of sugar cane froghoppers. In: WILLIAMS, J.R.; METCALFE, J.R.; MUNGOMERY, R.W.; MATHES, R. (Ed.) Pests of sugar cane. Amsterdam: Elsevier Publishing, 1969. cap.14, p.281-307.

GARCIA, J.F. Técnica de criação e tabela de vida de Mahanarva fimbriolata (Stål, 1854) (Hemiptera: Cercopidae). Piracicaba: USP/ ESALQ, 2002. 59p. (Dissertação - Mestrado).

GUAGLIUMI, P. As cigarrinhas dos canaviais no Brasil. Brasil Açucareiro, v.72, p.34-43, 1968.

MAIA, H.N.M.; LUIZ, A.J.B.; CAMPANHOLA, C. Statistical inference on associated fertility life table parameters using jackknife technique: computational aspects. Journal of Economic Entomology, v.93, p.511-518, 2000.

MARQUES, E.J. Biologia e avaliação de danos da cigarrinha da folha Mahanarva posticata (Stål, 1855) (Hom., Cercopidae) em cana-deaçúcar. Piracicaba: USP/ESALQ, 1976. 91p. (Dissertação Mestrado).

MENDES, A.C.; BOTELHO, P.S.M.; MACEDO, N.; SILVEIRA NETO, $\mathrm{S}$. Behavior of the adults of the root froghopper, Mahanarva fimbriolata (Stål, 1854) (Hom., Cercopidae), according to climatic parameters. In: INTERNATIONAL SOCIETY OF SUGAR CANE TECHNOLOGISTS CONGRESS, 16., São Paulo, 1977. Proceedings. São Paulo: ISSCT, 1977. p.617-631.

MEYER, J.S.; INGERSOLL, C.G.; MCDONALD, L.L.; BOYCE, M.S. Estimating uncertainty in population growth rates: jackknife vs. Bootstrap techniques. Ecology, v.67, p.1156-1166. 1986.

MOREIRA, C.A. Cigarrinha vermelha da cana de assucar (Tomaspis liturata Lep. \& Serv.). Boletim do Instituto Biológico de Defesa Agrícola, v.4, p.1-23, 1925.

Received December 02, 2005

Accepted July 04, 2006 